\title{
Flooding and streamflow in Utah during water year 2005
}

In the world there is nothing more submissive and weak than water. Yet for attacking that which is hard and strong nothing can surpass it.

Lao Tzu

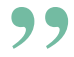

\section{Introduction}

The 2004 and 2005 water years illustrate why water managers in Utah generally describe the water supply as 'feast or famine.' In September 2004, Utah was finishing its sixth year of drought. Most reservoirs were substantially drained and the soil was parched. In contrast, in September 2005 Utah was finishing a water year that set new records for peak discharge and total annual streamflow.

The 2004 water year ended on September 30,2004 . The 2005 water year brought with it a significant change in the weather, beginning with intense rainfall in the Virgin River basin of southwestern Utah. Only minor flooding resulted from this storm; however, it provided soil moisture that would contribute to severe flooding during January 2005 (figs. 1 and 2).

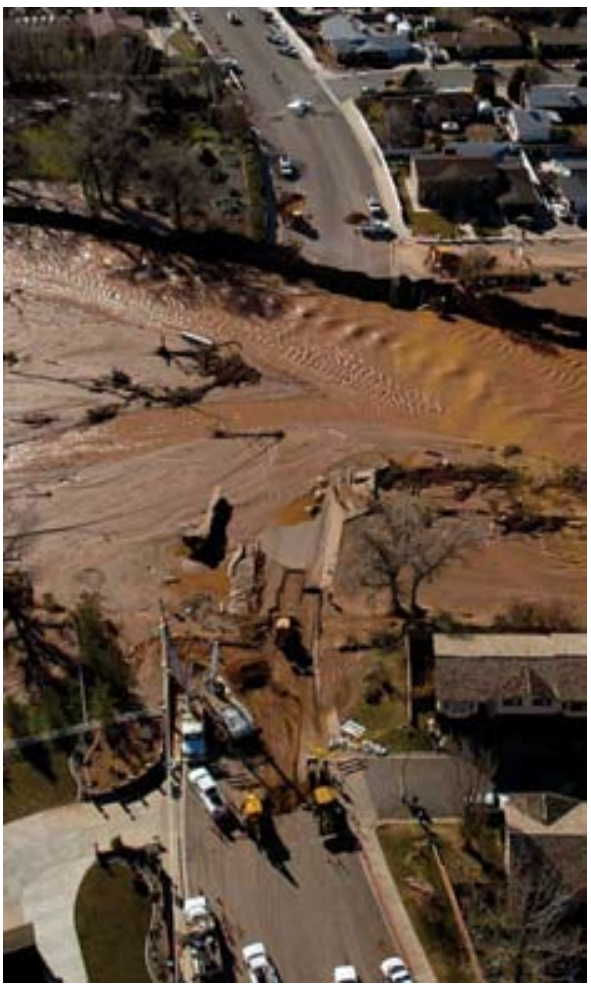

Figure 1. Bridge washed out by the Santa Clara River in St. George, Utah, January 2005. (Photo by Trent Nelson, Salt Lake Tribune).

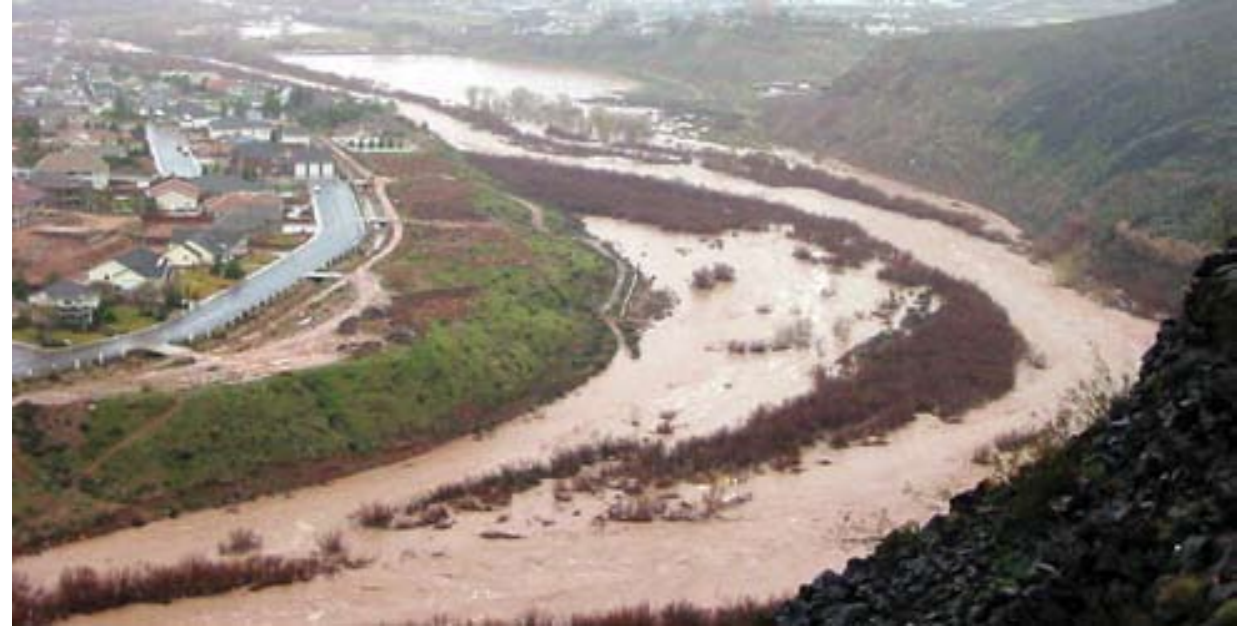

Figure 2. Virgin River near Washington, Utah, just upstream of the Santa Clara River. Discharge is approximately 12,000 cubic feet per second. View looking downstream on January 10, 2005. (Photo by D.E. Wilberg, U.S. Geological Survey).
In the high mountains and plateaus of Utah, these and subsequent storms built up a snowpack that reached record depths in some areas by the spring of 2005 (Julander and others, 2005). On April 28, 2005, heavy rain falling on snow in the Cache Valley area near Logan caused the next serious flood event. One month later, in late May and early June, the record snows began to melt and produced record runoff along the upper Sevier River in southern Utah and the Whiterocks River in northeastern Utah.

Eleven streamflow-gaging stations have been selected to highlight the flooding that occurred in Utah during water year 2005 (fig. 3). Of the selected stations, five set new records for peak discharge. Eight stations set records for total annual streamflow. Additional data for these and other stations in Utah can be obtained from Wilberg and others (2006).

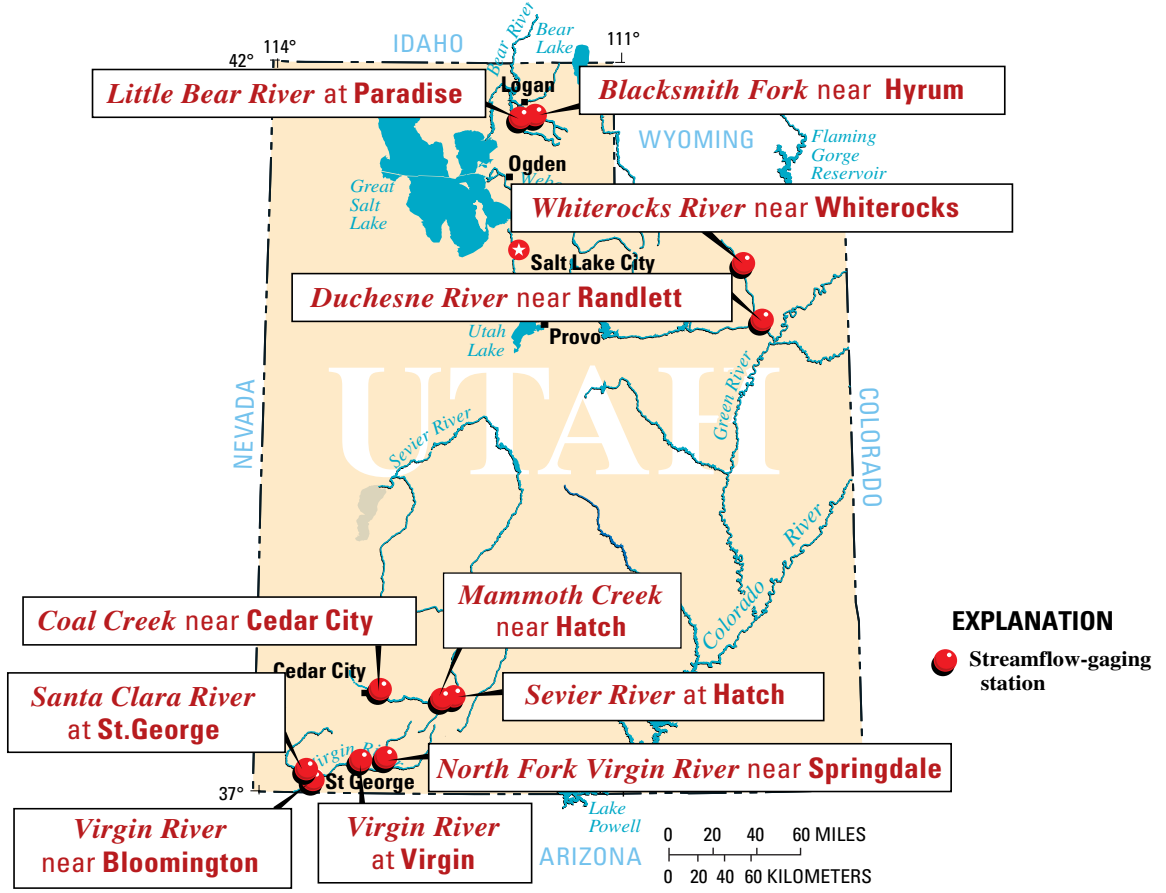

Figure 3. Selected streamflow-gaging stations in Utah. 


\section{Precipitation in Water Year 2005}

Precipitation in Utah results from three general atmospheric conditions: Pacific frontal systems (late fall through early spring), cutoff low-pressure systems (late spring and fall), and monsoonal thunderstorms (summer). Frontal systems typically move westto-east across Utah and account for much of the mountain snowpack (U.S. Geological Survey, 1991). These systems can affect all or part of the state, depending on the prevailing jet stream (high-altitude winds). Cutoff low-pressure systems generally originate in the Pacific Ocean, are widespread and slow moving, and can produce large amounts of precipitation over an extended time (U.S. Geological Survey, 1991). These are typically dissipating tropical cyclones, including tropical storms and hurricanes. Monsoonal thunderstorms frequently occur during the summer months when high temperatures and heating of the Earth's surface produce strong thermals. Subtropical moisture originating in the Gulf of Mexico and Gulf of California can combine with these thermals and produce locally intense thunderstorms.

The greatest percentage of flow for most streams in Utah comes from melting mountain snowpack that generally occurs in May and June. This runoff may produce some flooding along lower reaches of rivers, but damage from these type of flows is generally small (Western Regional Climate Center, 2006). The most common flooding in Utah comes from flash floods that occur as a result of a locally heavy precipitation event. Flash floods can occur throughout the year and across the state. A combination of intense rain on top of melting snow generally produce the largest and most damaging floods in the state.

During water year 2005, the flooding and high spring runoff was the direct result of a wet, southerly Pacific storm track that was attributed to a weak El Niño event (Brian McInerney, National Weather Service, oral commun., 2006). Starting in October 2004 , this storm track produced heavy snows in the mountains and plateaus of southwestern Utah and along the south slope of the Uinta Mountains. It also produced several large rainfall events that occurred during October, January, and April. During this time, adjacent areas of the southwestern United States, including southern California, Arizona, New Mexico, and southern Colorado also experienced greater-than-normal precipitation. The Pacific Northwest, Montana, and areas of Wyoming, however, received substantially less-than-normal precipitation.

Snowpack in Utah on April 1, 2005, is shown in table 1 . Snowpack ranged from 102 percent of average in the Bear River basin (north) to 234 percent of average in the southwestern mountains (Julander and others, 2005). Average soil-moisture conditions throughout Utah as of April 1, 2005, also are shown in table 1. Soil-moisture conditions can play an important role in the degree of
Table 1. Snowpack and soil moisture in selected areas in Utah on April 1, 2005

\begin{tabular}{|ccc}
\hline & $\begin{array}{c}\text { Snowpack, } \\
\text { in percent of } \\
\text { average }\end{array}$ & $\begin{array}{c}\text { Soil moisture, } \\
\text { in percent of } \\
\text { saturation }\end{array}$ \\
\hline Bear River basin & 102 & 71 \\
\hline $\begin{array}{c}\text { Weber and Ogden } \\
\text { River basins }\end{array}$ & 121 & 72 \\
\hline $\begin{array}{c}\text { Jordan River and } \\
\text { Tooele Valley } \\
\text { basins }\end{array}$ & 133 & 68 \\
\hline Uinta Mountains & 154 & 64 \\
\hline Southeastern Utah & 139 & 70 \\
\hline
\end{tabular}

flooding in an area. If soil-moisture conditions are low, much of the melting snow or falling rain will enter the ground. If soils are saturated, or if rain falls on an impermeable surface such as exposed bedrock, a much higher percentage of the precipitation will become streamflow. Soil moisture in Utah on April 1, 2005, ranged from 64 to 74 percent of saturation as measured in the upper 2 feet of soil (Julander and others, 2005). Soilmoisture in this range is considered adequate for an efficient runoff.

\section{Flood Events in Water Year 2005}

Maximum instantaneous discharge recorded during the 2005 water year is shown in table 2 for 11 selected streamflow-gaging stations in Utah. Several of these stations

Table 2. Maximum discharge data from 11 streamflow-gaging stations in Utah that were affected by flooding during water year 2005

[ft3/s, cubic feet per second; -, no data; >, greater than]

\begin{tabular}{|c|c|c|c|c|c|c|c|}
\hline Station name & Period of record & $\begin{array}{c}2005 \text { maximum instan- } \\
\text { taneous discharge } \\
\left(\mathrm{ft}^{3} / \mathrm{s}\right)\end{array}$ & $\begin{array}{l}\text { Date of } 2005 \\
\text { maximum in- } \\
\text { stantaneous } \\
\text { discharge }\end{array}$ & $\begin{array}{l}2005 \text { percentile of } \\
\text { yearly maximum } \\
\text { instantaneous } \\
\text { discharge }\end{array}$ & $\begin{array}{l}\text { Recurrence interval } \\
\text { of } 2005 \text { maximum } \\
\text { instantaneous } \\
\text { discharge }\end{array}$ & $\begin{array}{c}\text { Maximum } \\
\text { instantaneous } \\
\text { discharge for } \\
\text { period of record } \\
\left(f t^{3} / s\right)\end{array}$ & $\begin{array}{c}\text { Date of maximum } \\
\text { instantaneous } \\
\text { discharge for period } \\
\text { of record }\end{array}$ \\
\hline \multicolumn{8}{|c|}{ Virgin River Basin } \\
\hline North Fork Virgin River near Springdale, Utah & $1925-2005$ & 5,450 & $1 / 11 / 2005$ & 94 & $10-25$ years $^{1}$ & 9,150 & $12 / 6 / 1966$ \\
\hline Virgin River at Virgin, Utah & 1910-1971, 1978-2005 & 9,840 & $1 / 11 / 2005$ & 82 & $10-25$ years $^{1}$ & 22,800 & $12 / 6 / 1966$ \\
\hline Santa Clara River at St. George, Utah & 1950-1956, 1984-2005 & 6,200 & $1 / 11 / 2005$ & 100 & $25-50$ years $^{1}$ & 6,200 & $1 / 11 / 2005$ \\
\hline Virgin River near Bloomington, Utah & $1978-2005$ & 19,600 & $1 / 11 / 2005$ & $100^{2}$ & $>100$ years $^{1}$ & $19,600^{2}$ & $1 / 11 / 2005$ \\
\hline \multicolumn{8}{|c|}{ Cache Valley } \\
\hline Little Bear River at Paradise, Utah & $1993-2005$ & 4,800 & $4 / 28 / 2005$ & 100 & $>100$ years $^{3}$ & 4,800 & $4 / 28 / 2005$ \\
\hline Little Bear River near Paradise, Utah & $1937-1986$ & - & - & - & - & 2,250 & $2 / 19 / 1986$ \\
\hline Blacksmith Fork near Hyrum, Utah & $\begin{array}{c}\text { 1915-1917, 1919-1996 } \\
\text { 2001-2005 }\end{array}$ & 1,570 & $4 / 28 / 2005$ & 97 & $25-50$ years $^{3}$ & 1,650 & $5 / 14 / 1984$ \\
\hline \multicolumn{8}{|c|}{ Sevier River Basin } \\
\hline Mammoth Creek near Hatch, Utah & $1965-2005$ & 1,390 & $6 / 3 / 2005$ & 100 & $>100$ years $^{3}$ & 1,390 & $6 / 3 / 2005$ \\
\hline Sevier River at Hatch, Utah & $1915-1928,1940-2005$ & 1,990 & $6 / 3 / 2005$ & 100 & $>100$ years $^{3}$ & 1,990 & $6 / 3 / 2005$ \\
\hline Coal Creek near Cedar City, Utah & $1939-2005$ & 1,690 & $6 / 3 / 2005$ & 74 & $5-10$ years $^{3}$ & 4,620 & $7 / 23 / 1969$ \\
\hline \multicolumn{8}{|c|}{ Duchesne River Basin } \\
\hline Whiterocks River near Whiterocks, Utah & $1930-2005$ & 1,920 & $5 / 23 / 2005$ & 81 & $5-10$ years $^{3}$ & 4,640 & $6 / 22 / 1983$ \\
\hline Duchesne River near Randlett, Utah & $1943-2005$ & 7,570 & $5 / 26 / 2005$ & 92 & $5-10$ years $^{3}$ & 11,500 & $6 / 20 / 1983$ \\
\hline
\end{tabular}

${ }^{1}$ Weighted estimates using regional regression equations (Thomas and others, 1997) and guidelines outlined in Bulletin 17B.

(U.S. Interagency Advisory Committee on Water Data, 1982).

${ }^{2}$ Does not include failure of Quail Creek Reservoir dike in $1989\left(60,000 \mathrm{ft}^{3} / \mathrm{s}\right)$.

${ }^{3}$ Estimate computed following guidelines outlined in Bulletin 17B (U.S. Interagency Advisory Committee on Water Data, 1982). 
set new maximum instantaneous discharge records in 2005. All of the stations in table 2 had a maximum instantaneous discharge that exceeded the $70^{\text {th }}$ percentile.

\section{Virgin River Basin}

Streamflow in the Virgin River at the start of water year 2005 was below average baseflow conditions. Monthly mean discharges for June through September 2004 at U.S. Geological Survey (USGS) streamflow-gaging station Virgin River at Virgin, Utah, averaged more than 50 percent less than the monthly mean discharge for these same months during the 89-year period of record.

In southwestern Utah, soil moisture in the upper 2 feet of soil on October 1, 2004, was estimated at about 30 percent of saturation by the Utah Snow Survey Program of the Natural Resources Conservation Service (NRCS) (Randall Julander, written commun., 2005). During October 18-22, 2004, a Pacific frontal moisture system delivered between 1.5 and 9.4 inches of rain in the Virgin River basin above the confluence with the Santa Clara River (fig. 4). The precipitation data shown in figure 4 is an estimate produced by the National Weather Service from Next Generation Weather Radar, or NEXRAD (National Oceanic and Atmospheric Administration, 2006). The apparent total volume of water that fell as precipitation from this storm was 493,000 acre-feet, as calculated from the NEXRAD data. The resultant peak discharge that occurred on October 21 on the Virgin River near Bloomington, Utah, was about 11,000 cubic feet per second $\left(\mathrm{ft}^{3} / \mathrm{s}\right.$ ) (fig. 5). Peak discharge on the Santa Clara River at St. George, Utah, was 1,190 $\mathrm{ft}^{3} / \mathrm{s}$ (fig. 5). These peaks correspond to about a 5- to 10year flow recurrence interval. Minor damage was reported along Ash Creek and the upper reaches of the Santa Clara River in the Pine Valley area.

During January 8-12, 2005, another large, wet Pacific frontal system moved into the Virgin River basin in Utah. This system delivered between 0.7 and 7.7 inches of rain (fig. 6). The total apparent volume of precipitation from the January storm was about half as much as the October event, or 264,000 acre-feet. However, as a result of the October storm, the soil-moisture at the time was estimated to be 70 percent of saturation (Julander and others, 2005).

On the evening of January 8, 2005, light rain began to fall in the Virgin River basin. The highest-intensity precipitation of the event occurred on January $9^{\text {th }}$, and streamflow rose rapidly in response (fig. 7). Initial peaks of $4,890 \mathrm{ft}^{3} / \mathrm{s}$ on the Santa Clara River at St. George, and 19,000 $\mathrm{ft}^{3} / \mathrm{s}$ at the Virgin River near Bloomington occurred on the morning of the $10^{\text {th }}$. At this time, numerous roads were closed and a State of Emergency
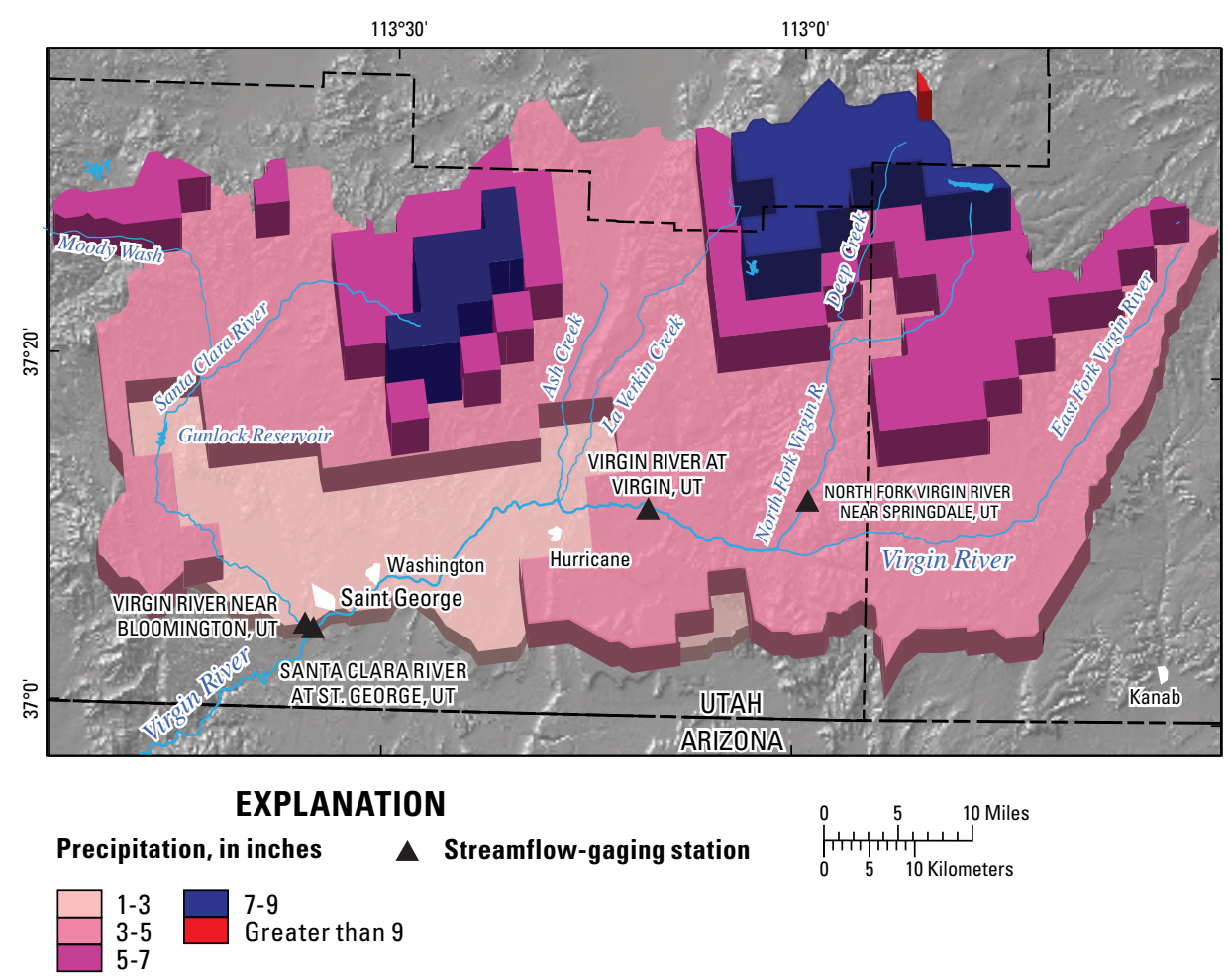

Figure 4. Storm-total precipitation calculated from National Weather Service Next Generation Radar data for the Virgin River basin, Utah, October 18-22, 2004. was declared. Flows began to recede by the late afternoon on the $10^{\text {th }}$. Additional rain on January 11, however, brought discharge to record levels in the Santa Clara River at St. George, and the Virgin River near Bloomington. The peak discharge for the Santa Clara River on January 11, 2005, was $6,200 \mathrm{ft}^{3} / \mathrm{s}$ (table 2), resulting in the collapse of several houses into the Santa Clara River as the river shifted its course. The peak discharge on January 11, 2005, for the Virgin River near Bloomington was $19,600 \mathrm{ft}^{3} / \mathrm{s}$ (table 2).

The floods along the Santa Clara River caused 28 homes to be destroyed or damaged, resulting in an estimated $\$ 85$ million in personal property damage. The floods caused an additional $\$ 140$ million in damage to local infrastructure (Ryan Pietramali, Utah Department of Public Safety, written commun., 2006).

\section{Cache Valley}

On April 28, 2005, heavy localized precipitation, believed to be in part a rain-on-snow event, caused flooding in Cache Valley in northern Utah. Peak discharge at streamflow-gaging station Little Bear River at Paradise, Utah, for this event was $4,800 \mathrm{ft}^{3} / \mathrm{s}$ (table 2), or more than $3,500 \mathrm{ft}^{3} / \mathrm{s}$ more than the previous recorded maximum discharge. From 1937 to 1986 a station was operated at a location 1 mile downstream from the present site. When compared to this record, the peak from April 28, 2005, was nearly twice as large as any previously recorded discharge. Peak discharge on the nearby Blacksmith Fork River did not break a record for the 87year history of the gage; however, discharge was at the $97^{\text {th }}$ percentile during the flood event (table 2).

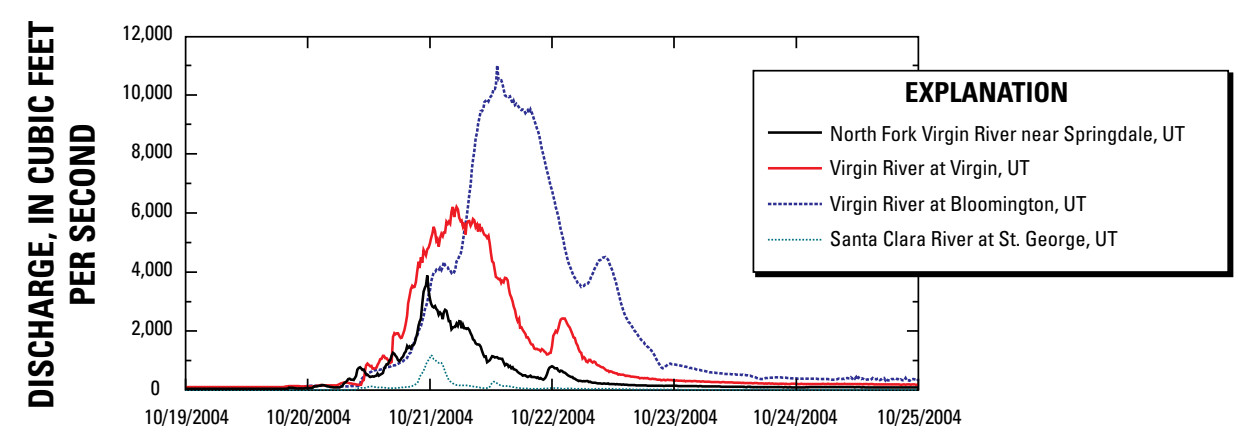

Figure 5. Discharge at selected streamflow-gaging stations in the Virgin River basin for October 19-25, 2004. 


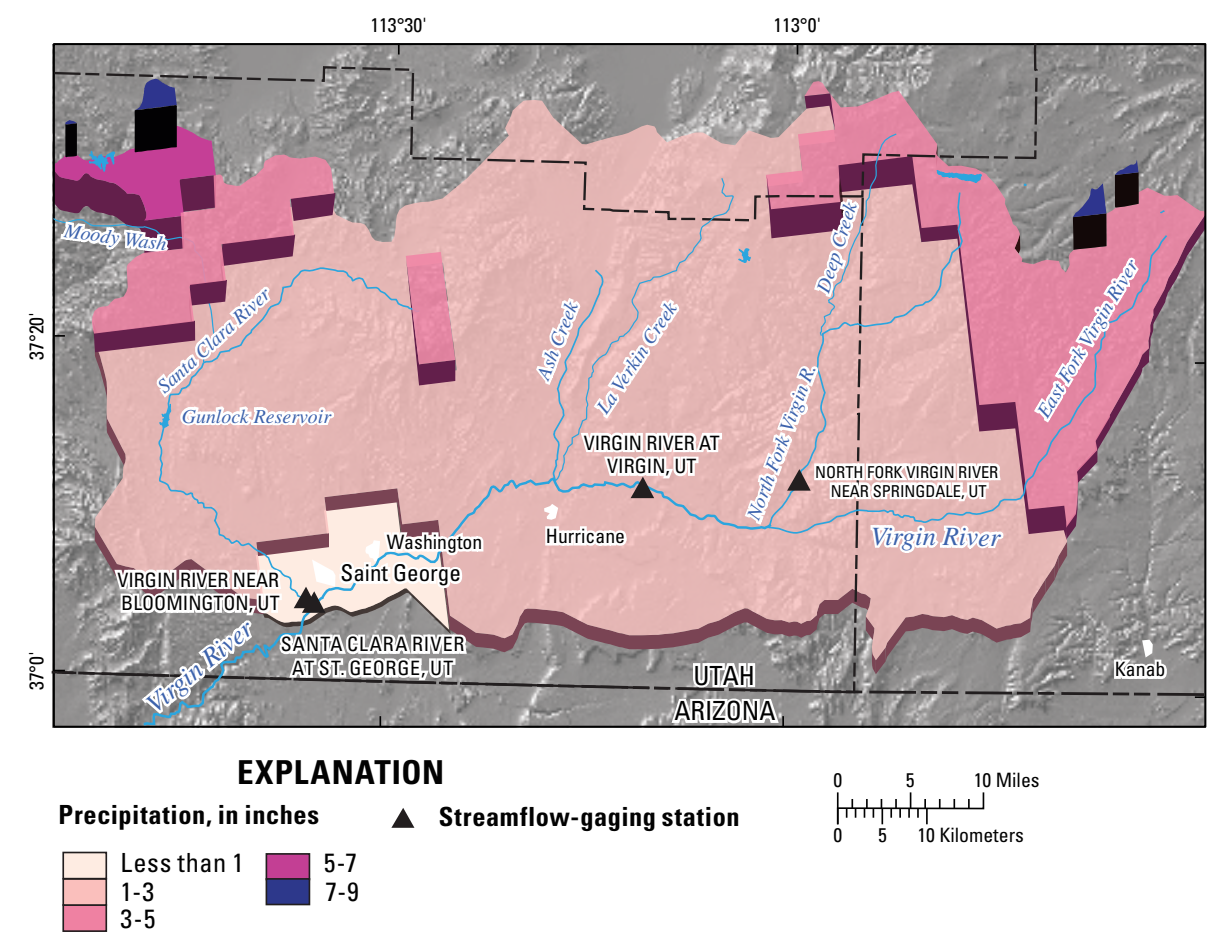

Figure 6. Storm-total precipitation calculated from National Weather Service Next Generation Radar data for the Virgin River basin, Utah, January 8-12, 2005.

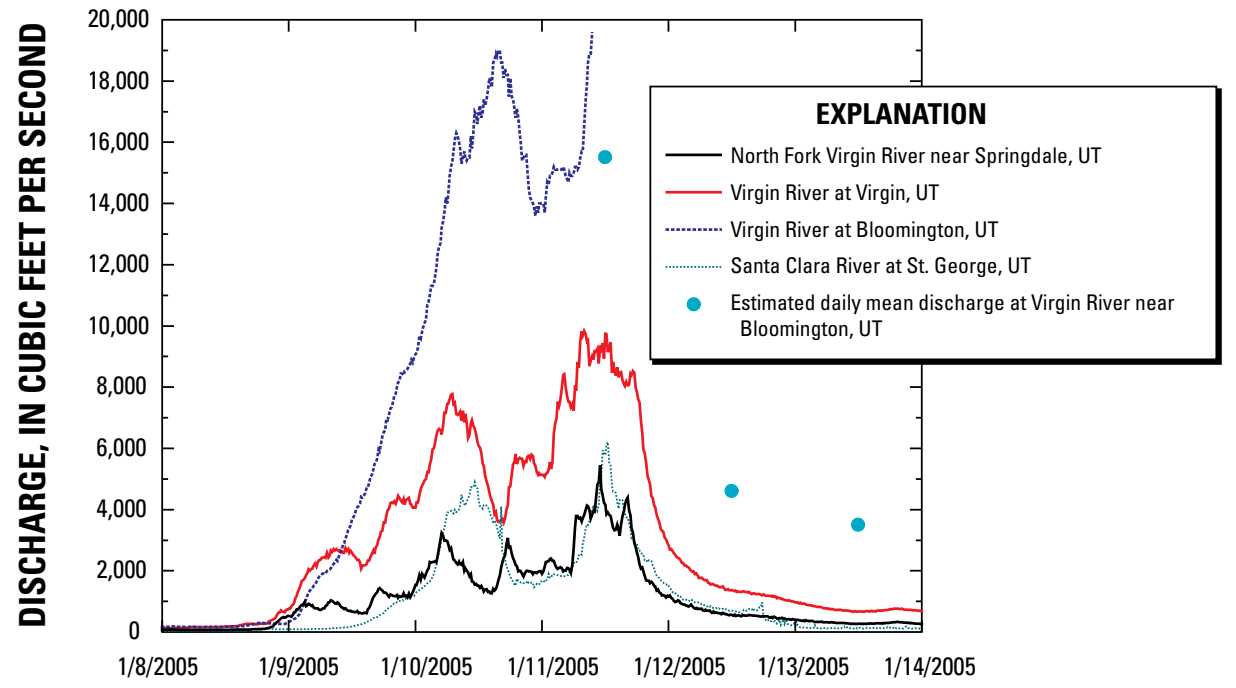

Figure 7. Discharge at selected streamflow-gaging stations in the Virgin River basin for January 8-14, 2005.

\section{Sevier River Basin}

The April 1, 2005, snowpack for the upper Sevier River basin was 225 percent of normal. The April 1, 2005, snowpack in the Coal Creek drainage basin was 242 percent of normal. Melt of this massive snowpack created new maximum discharge records for gages on the Sevier River at Hatch, Utah, and on Mammoth Creek near Hatch, Utah, a tributary of the Sevier River (table 2). Both summer as the result of heavy monsoonal rains. For comparison, the spring runoff peak of 1983 , a very wet year, was $1,480 \mathrm{ft}^{3} / \mathrm{s}$ (ReMillard and others, 1984).

The 2005 peak discharge for the Sevier River at Hatch, Utah, was $1,990 \mathrm{ft}^{3} / \mathrm{s}$. Peak discharge was $1,390 \mathrm{ft}^{3} / \mathrm{s}$ on Mammoth Creek near Hatch (table 2). Both peaks for the 2005 water year were maximum discharges for the period of record at these stations. Some flooding of cabins and road closures occurred along Mammoth Creek as a result of the spring flood peak. The reaches of the lower Sevier River were spared flood damage because reservoirs located downstream of Hatch captured a substantial amount of the runoff.

\section{Duchesne River Basin}

The April 1, 2005, snowpack for the entire Duchesne River basin was 164 percent of normal (Julander and others, 2005). For the Whiterocks River in the upper part of the Duchesne River basin, the April 1, 2005, snowpack was 226 percent of normal (Julander and others, 2005). This greaterthan-normal snowpack caused some concern during the spring of 2005, raising fears that a rapid temperature increase or a rain-on-snow event in late spring would cause flooding on the Whiterocks or Duchesne Rivers. Daily mean discharge for the Whiterocks River near Whiterocks in relation to daily snow-water equivalent measured at the NRCS Chepeta SNOTEL site is shown in figure 8 . The maximum recorded discharge for Whiterocks River near Whiterocks during the 2005 water year was $1,920 \mathrm{ft}^{3} / \mathrm{s}$. The maximum discharge for the period of record was 4,640 $\mathrm{ft}^{3} / \mathrm{s}$ and occurred June 22, 1983 (table 2). The cooler temperatures at the end of May 2005 most likely prevented a peak of similar magnitude to 1983 .

The maximum discharge recorded on the Duchesne River near Randlett during water year 2005 was $7,570 \mathrm{ft}^{3} / \mathrm{s}$ (table 2). This peak was greater than the $90^{\text {th }}$ percentile of recorded discharge for this station.

\section{Total Annual Discharge for Water Year 2005}

Total annual discharge at 11 streamflowgaging stations in Utah is shown in table 3. At the selected stations, total annual discharge ranged from 98 percent of average at Blacksmith Fork near Hyrum to 773 percent of average on the Santa Clara River at St. George.

Record total annual discharge was measured at stations on the North Fork of the Virgin River near Springdale; the Virgin River at Virgin; the Santa Clara River at St. George; 
the Virgin River near Bloomington; Coal Creek near Cedar City; the Sevier River at Hatch, and Mammoth Creek near Hatch. The record total annual discharge at these stations was produced by snowpacks that were also near or above historic maximums (Julander and others, 2005). In contrast, the Little Bear River and Blacksmith Fork River experienced localized flooding on April 28, 2005, but had near average total annual discharge (table 3 ).
Total annual discharge for stations in the Virgin River basin ranged from 261 percent of average for the Virgin River at Virgin to 773 percent of average for the Santa Clara River at St. George. A hydrograph with daily mean discharge for the 2005 water year along with the historic daily median discharges is shown in figure 9. The hydrograph shows that daily mean discharges were greater than the median discharges for nearly the entire water year. These sustained above-normal

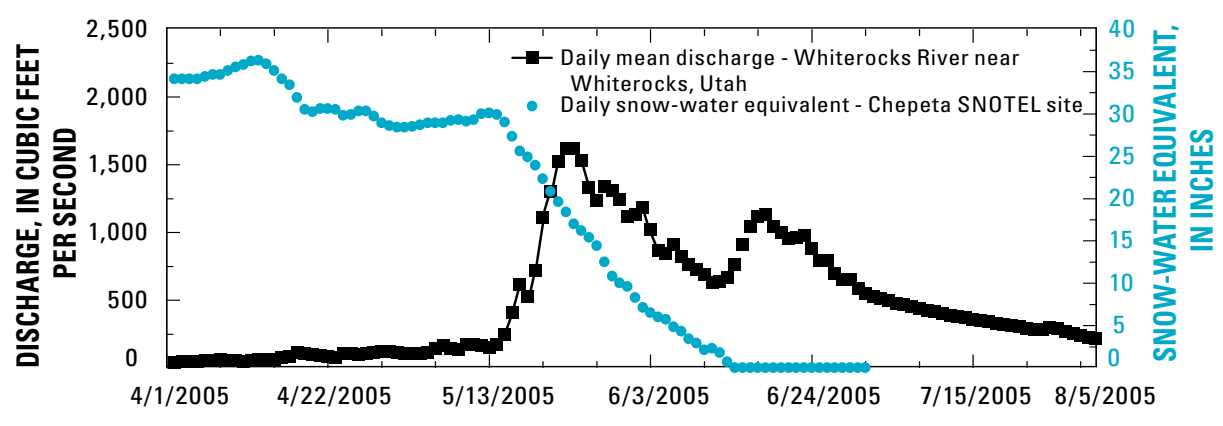

Figure 8. Relation of daily mean discharge for Whiterocks River near Whiterocks, Utah, to snowwater equivalent measured at the Chepeta SNOTEL site during the spring of 2005. discharges combined with the flash flooding in October and January caused the exceedingly high total annual runoff on the Santa Clara River (table 3).

The total annual discharge for Whiterocks River near Whiterocks, Utah, which is a tributary of the Duchesne River, set a new record during water year 2005 and was nearly twice the average amount (table 3 ). The snowpack in the sub-basin directly above this station, measured at the Chepeta SNOTEL site was 226 percent of normal. Snowpack for the entire Duchesne River basin was 164 percent of normal; however, total annual discharge for the station on the Duchesne River near Randlett was only at the $79^{\text {th }}$ percentile, which is considered slightly above normal.

\section{Summary}

During water year 2005, new historic maximum discharge records were set at streamflow-gaging stations on the Santa Clara River at St. George; Virgin River near Bloomington; Little Bear River at Paradise; Mammoth Creek near Hatch; and Sevier River at Hatch.

Table 3. Annual streamflow data from 11 streamflow-gaging stations in Utah that were affected by flooding during water year 2005 [kac-ft, thousands of acre-feet]

\begin{tabular}{|c|c|c|c|c|c|}
\hline Station name & Period of record & $\begin{array}{l}\text { Average total annual } \\
\text { discharge for period } \\
\text { of record (kac-ft) }\end{array}$ & $\begin{array}{l}2005 \text { total annual } \\
\text { discharge (kac-ft) }\end{array}$ & $\begin{array}{l}2005 \text { percent of } \\
\text { average total annual } \\
\text { discharge }\end{array}$ & $\begin{array}{l}2005 \text { percentile of total } \\
\text { annual discharge }\end{array}$ \\
\hline \multicolumn{6}{|c|}{ Virgin River Basin } \\
\hline North Fork Virgin River near Springdale, Utah & $1926,1928-2005$ & 75 & 232 & 309 & 100 \\
\hline Virgin River at Virgin, Utah & 1910-1971, 1978-2005 & 145 & 379 & 261 & 100 \\
\hline Santa Clara River at St. George, Utah & $1950-1956,1984-2005$ & 11 & 85 & 773 & 100 \\
\hline Virgin River near Bloomington, Utah & $1978-2005$ & 172 & 549 & 319 & 100 \\
\hline \multicolumn{6}{|c|}{ Cache Valley } \\
\hline Little Bear River at Paradise, Utah & $1993-2005$ & 65 & 86 & 132 & 75 \\
\hline Blacksmith Fork near Hyrum, Utah & $\begin{array}{c}\text { 1915-1917, 1919-1996, } \\
2001-2005\end{array}$ & 91 & 89 & 98 & 56 \\
\hline \multicolumn{6}{|c|}{ Sevier River Basin } \\
\hline Mammoth Creek near Hatch, Utah & $1965-2005$ & 36 & 115 & 319 & 100 \\
\hline Sevier River at Hatch, Utah & $1915-1928,1940-2005$ & 87 & 245 & 282 & 100 \\
\hline Coal Creek near Cedar City, Utah & $1939-2005$ & 25 & 84 & 336 & 100 \\
\hline \multicolumn{6}{|c|}{ Duchesne River Basin } \\
\hline Whiterocks River near Whiterocks, Utah & $1930-2005$ & 82 & 158 & 193 & 100 \\
\hline Duchesne River near Randlett, Utah & 1943-2005 & 388 & 578 & 149 & 79 \\
\hline
\end{tabular}




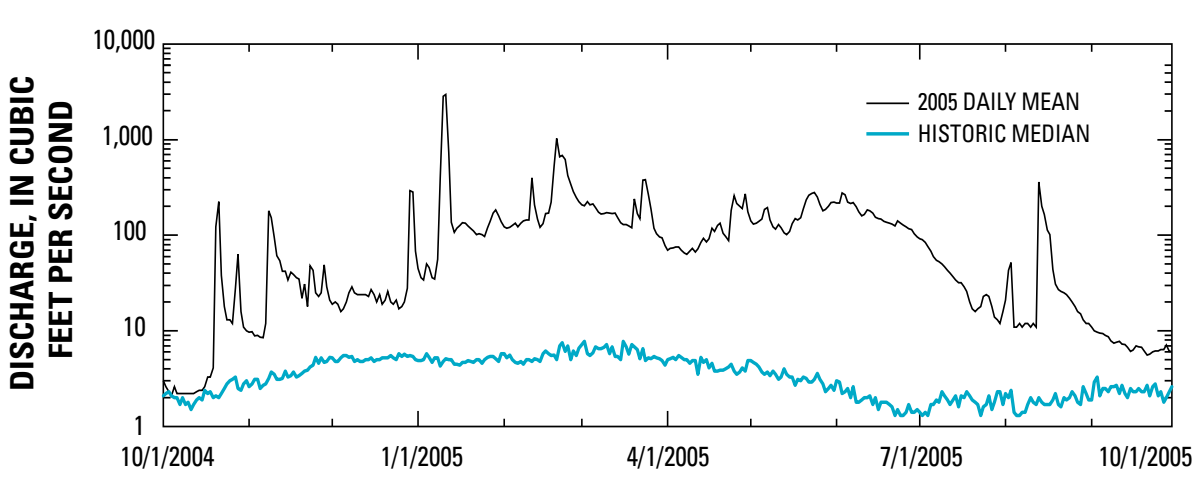

Figure 9. Hydrograph for Santa Clara River at St. George, Utah.

New total annual discharge records were set at Whiterocks River near Whiterocks; North Fork of the Virgin River near Springdale; Virgin River at Virgin; Santa Clara River at St. George; Virgin River near Bloomington; Mammoth Creek near Hatch; Sevier River at Hatch; and Coal Creek near Cedar City. New peak instantaneous discharge records were set on the Santa Clara, Virgin, and Little Bear Rivers as a result of locally intense rainfall events. The record peak discharges set on Mammoth Creek and the Sevier River were the result of snowpacks that were substantially greater than normal. The total annual discharge records for all of the stations were the result of greater-than-normal precipitation during the winter of 2005 caused by a weak El Niño event.

\section{USGS Streamflow-Monitoring Program}

For more than 100 years, the USGS Utah Water Science Center has been collecting streamflow data in Utah with support from Federal, State, and local cooperators. The USGS operates more than 150 streamflowmost of these stations are available on the ut.water.usgs.gov.

For more information contact:

U.S. Geological Survey

2329 West Orton Circle

Salt Lake City, Utah 84119

801.908.5000 gaging stations in Utah. Real-time data from Utah Water Science Center website at_http://

http://ut.water.usgs.gov

By C.D. Wilkowske, T.A. Kenney, and T.S. McKinney

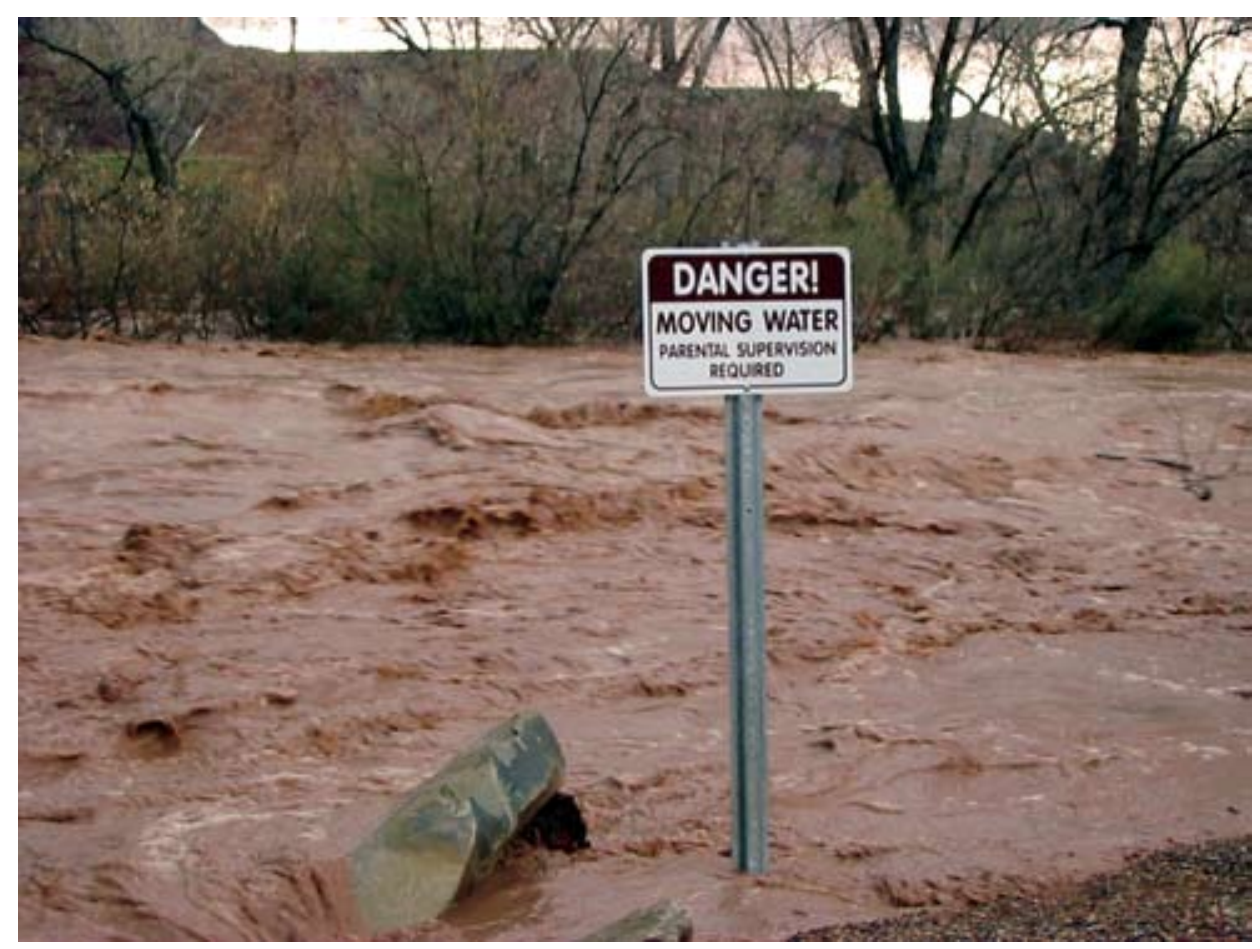

\section{References}

Julander, R., Wilson, R., Bardsley, T., Bricco, M., and Nault, B., 2005, Utah water supply outlook report, April 2005: Natural Resources Conservation Service, accessed February 23, 2006, at http://www.ut.nrcs. usda.gov/snow/watersupply/wsor/ 2005/wsor_0405.pdf

National Oceanic and Atmospheric Admistration, 2006, National stage IV QPE product: National Weather Service, National Center for Environmental Prediction, Precipitation 4KM stage IV data, accessed March 6, 2006, at_http:// www.emc.ncep.noaa.gov/mmb/ylin/ pcpanl/stage4/

ReMillard, M.D., Birdwell, G.A., Garrett, R.B., and Sandberg, G.W., 1984, Water resources data for Utah, water year 1983, U.S. Geological Survey Water-Data Report UT-83-1, 489 p.

Thomas, B.E., Hjalmarson, H.W., and Waltemeyer, S.D., 1997, Methods for estimating magnitude and frequency of floods in the southwestern United States, U.S. Geological Survey Water-Supply Paper 2433, $195 \mathrm{p}$.

U.S. Geological Survey, 1991, National water summary, 1988-89: U.S. Geological Survey Water-Supply Paper 2375, 591 p.

U.S. Interagency Advisory Committee on Water Data, 1982, Guidelines for detemining flood flow frequency, Bulletin 17-B of the Hydrology Subcommittee: Reston, Virginia, U.S. Geological Survey, Office of Water Data Coordination, 183 p.

Western Regional Climate Center, 2006, Climate of Utah, accessed February 23, 2006, at http://www.wrcc.dri.edu/ narratives/UTAH.htm

Wilberg, D.E., Tibbetts, J.R., Enright, Michael, Burden, C.B., Smith, Cynthia, and Angeroth, C.E., 2006, Water resources data, Utah, water year 2005, U.S. Geological Survey Water-Data Report UT-05-1, 734 p.

Climate is what we expect, weather is what we get. 99 Mark Twain 